Toxicity Assessment of Sediments Collected Upstream and Downstream from the White Dam in Clarke County, Georgia

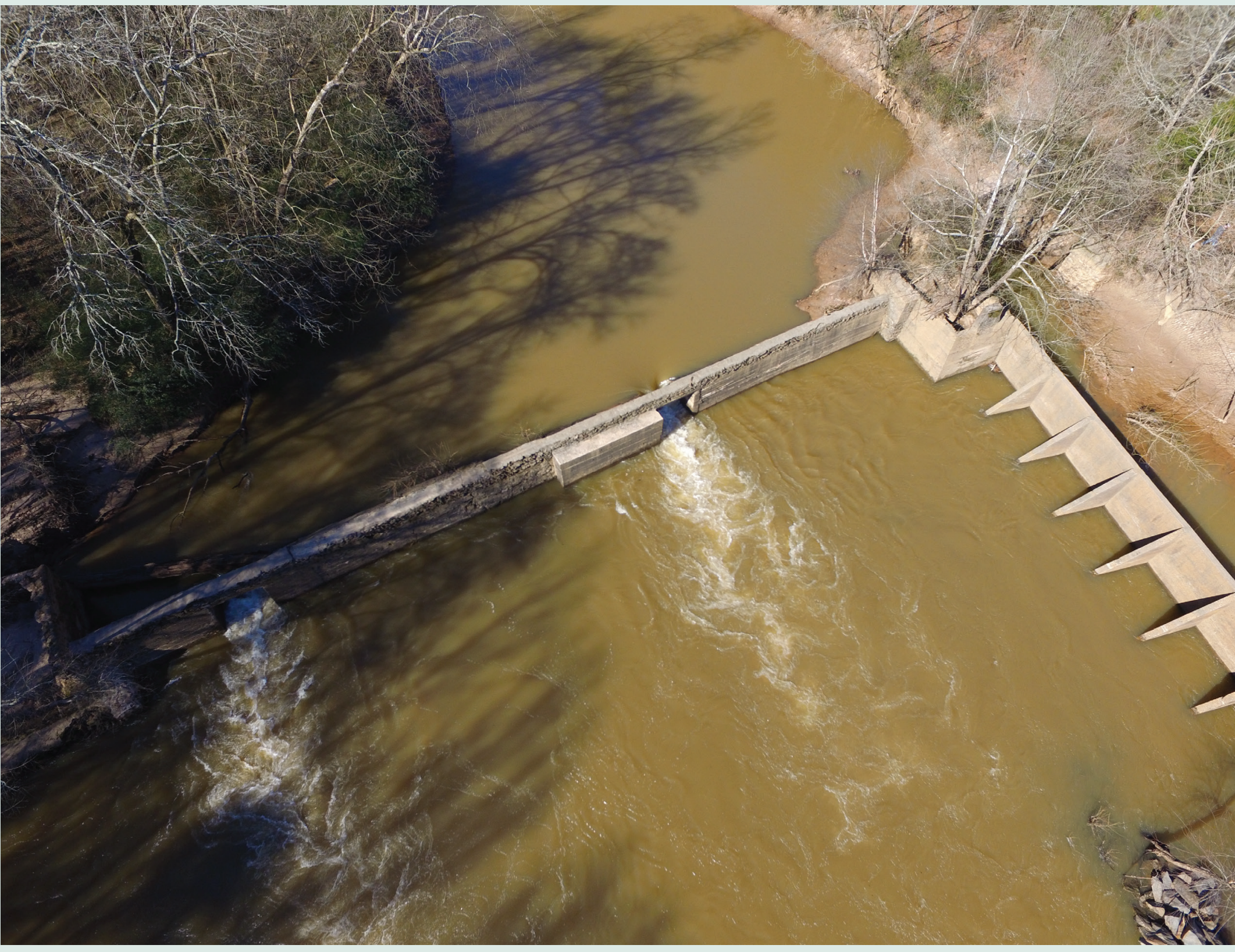

Open-File Report 2018-1036

U.S. Department of the Interior

U.S. Geological Survey 
Cover: Photograph of White Dam on the Middle Oconee River, Clarke County, Georgia. (Photograph by Dr. Roger C. Lowe, III, Warnell School of Forestry and Natural Resources, University of Georgia) 


\section{Toxicity Assessment of Sediments Collected Upstream and Downstream from the White Dam in Clarke County, Georgia}

By Peter J. Lasier

Open-File Report 2018-1036 


\section{U.S. Department of the Interior \\ RYAN K. ZINKE, Secretary}

\section{U.S. Geological Survey James F. Reilly II, Director}

\section{U.S. Geological Survey, Reston, Virginia: 2018}

For more information on the USGS - the Federal source for science about the Earth, its natural and living resources, natural hazards, and the environment-visit https://www.usgs.gov or call 1-888-ASK-USGS.

For an overview of USGS information products, including maps, imagery, and publications, visit https://store.usgs.gov.

Any use of trade, firm, or product names is for descriptive purposes only and does not imply endorsement by the U.S. Government.

Although this information product, for the most part, is in the public domain, it also may contain copyrighted materials as noted in the text. Permission to reproduce copyrighted items must be secured from the copyright owner.

Suggested citation:

Lasier, P.J., 2018, Toxicity assessment of sediments collected upstream and downstream from the White Dam in Clarke County, Georgia: U.S. Geological Survey Open-File Report 2018-1036, 6 p., https://doi.org/10.3133/ ofr20181036.

ISSN 2328-0328 (online) 


\section{Contents}

Abstract
Introduction.
Methods
$\quad$ Sample Collection and Preparation
$\quad$ Chexicity Assessments
$\quad$ Sediment Characterization Analyses





\section{Figures}

1. Map showing location of the White Dam southeast of Athens in

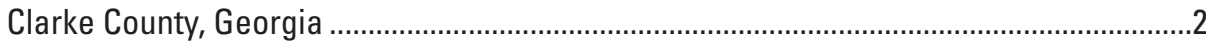

2. Graphs showing mean toxicity endpoints as horizontal lines including $A$, survival, $B$, growth, and $C$, reproduction of Hyalella azteca exposed to six sediments collected in the vicinity of the White Dam, Georgia, and a water-only treatment in 42-day assessments plus or minus one standard deviation. 4

\section{Tables}

1. Mean survival, 42-day dry weight per individual, and number of young per female with coefficients of variation of Hyalella azteca exposed to White Dam, Georgia, sediments, a water-only treatment, and artificial sediment

2. Physical characteristics of White Dam, Georgia, sediments and artificial sediment used in toxicity exposures.

3. Mean water-chemical parameters with coefficients of variation measured in moderately hard water used for toxicity exposures and overlying waters from exposure chambers containing White Dam, Georgia, sediments, a water-only treatment, and artificial sediment. .5

\section{Conversion Factors}

U.S. customary units to International System of Units

\begin{tabular}{lccc}
\hline & Multiply & By & To obtain \\
\hline & Length & \\
\hline foot $(\mathrm{ft})$ & 0.3048 & meter $(\mathrm{m})$ & \\
\hline
\end{tabular}

Temperature in degrees Celsius $\left({ }^{\circ} \mathrm{C}\right)$ may be converted to degrees Fahrenheit $\left({ }^{\circ} \mathrm{F}\right)$ as follows:

$$
{ }^{\circ} \mathrm{F}=\left(1.8 \times{ }^{\circ} \mathrm{C}\right)+32 \text {. }
$$

\section{Supplemental Information}

Specific conductance is given in microsiemens per centimeter at 25 degrees Celsius $\left(\mu \mathrm{S} / \mathrm{cm}\right.$ at $\left.25^{\circ} \mathrm{C}\right)$. 



\section{Toxicity Assessment of Sediments Collected Upstream and Downstream from the White Dam in Clarke County, Georgia}

By Peter J. Lasier

\section{Abstract}

The White Dam in Clarke County, Georgia, has been proposed for breaching. Efforts to determine potential risks to downstream biota included assessments of sediment collected in the vicinity of the dam. Sediments collected from sites upstream and downstream from the dam were evaluated for toxicity in 42-day exposures using the freshwater amphipod Hyalella azteca. Endpoints of the study were survival, growth, and reproduction of $H$. azteca. Results indicated no significant differences between the collected sediments and the wateronly treatment used for comparison of the test endpoints. Therefore, based on the laboratory experiments in this study, sediment migration downstream from a breach of the Dam may not pose a toxicity risk to downstream biota.

\section{Introduction}

The White Dam is on the Oconee River in Clarke County, Georgia, $500 \mathrm{ft}$ upstream from the confluence of the Middle and Upper Oconee Rivers (fig. 1).

A breach in the dam has been proposed to facilitate fish passage, and preliminary investigations of sediment conditions, type, and toxicity have been initiated. The U.S. Environmental Protection Agency (EPA) has conducted bathymetric and biotic assessments for the project. In 2017, the U.S. Geological Survey (USGS) provided toxicity assessments of sediment samples collected by EPA personnel. The objective of this study was to determine the toxicity of sediments collected upstream and downstream from the White Dam. This report presents the methods used to determine sediment toxicity and the results of the sediment assessments.

\section{Methods}

\section{Sample Collection and Preparation}

Composite sediment core samples were collected along transects parallel with the dam from three distances upstream (U; 25, 110, and 200 feet) and three distances downstream (D; 0, 50, and 110 feet) from the dam on February 9, 2017. Approximately 1 liter of sediment was subsampled from each composite and delivered to the USGS laboratory in Athens, Ga., where the sediments were immediately processed for testing. The sediments were homogenized by hand in a stainless steel bowl with a stainless steel spoon and subsampled for toxicity testing and sediment characterization.

\section{Toxicity Assessments}

Sediment toxicity was determined in 42-day exposures beginning on February10, 2017, using the amphipod Hyalella azteca (EPA 2000). Hyalella azteca is an aquatic invertebrate commonly used to evaluate chemical contamination in freshwater sediments. In general, 100 milliliters $(\mathrm{mL})$ of sediment was placed in a 300-mL high-form beaker with a screen-covered notch at the top and covered with $175 \mathrm{~mL}$ of reconstituted moderately hard water, which was automatically renewed three times per day with an addition of $125 \mathrm{~mL}$ of fresh water (Zumwalt and others, 1994). Exposure temperature was maintained at 23 degrees Celsius $\left({ }^{\circ} \mathrm{C}\right)$. The number of replicates (n) prepared for each sample was five. Ten 7-dayold $H$. azteca with mean dry weight (using 100 individuals) of 0.03 milligrams $(\mathrm{mg})$ were added to each beaker at test initiation and fed daily. Endpoints used for the toxicity assessment 


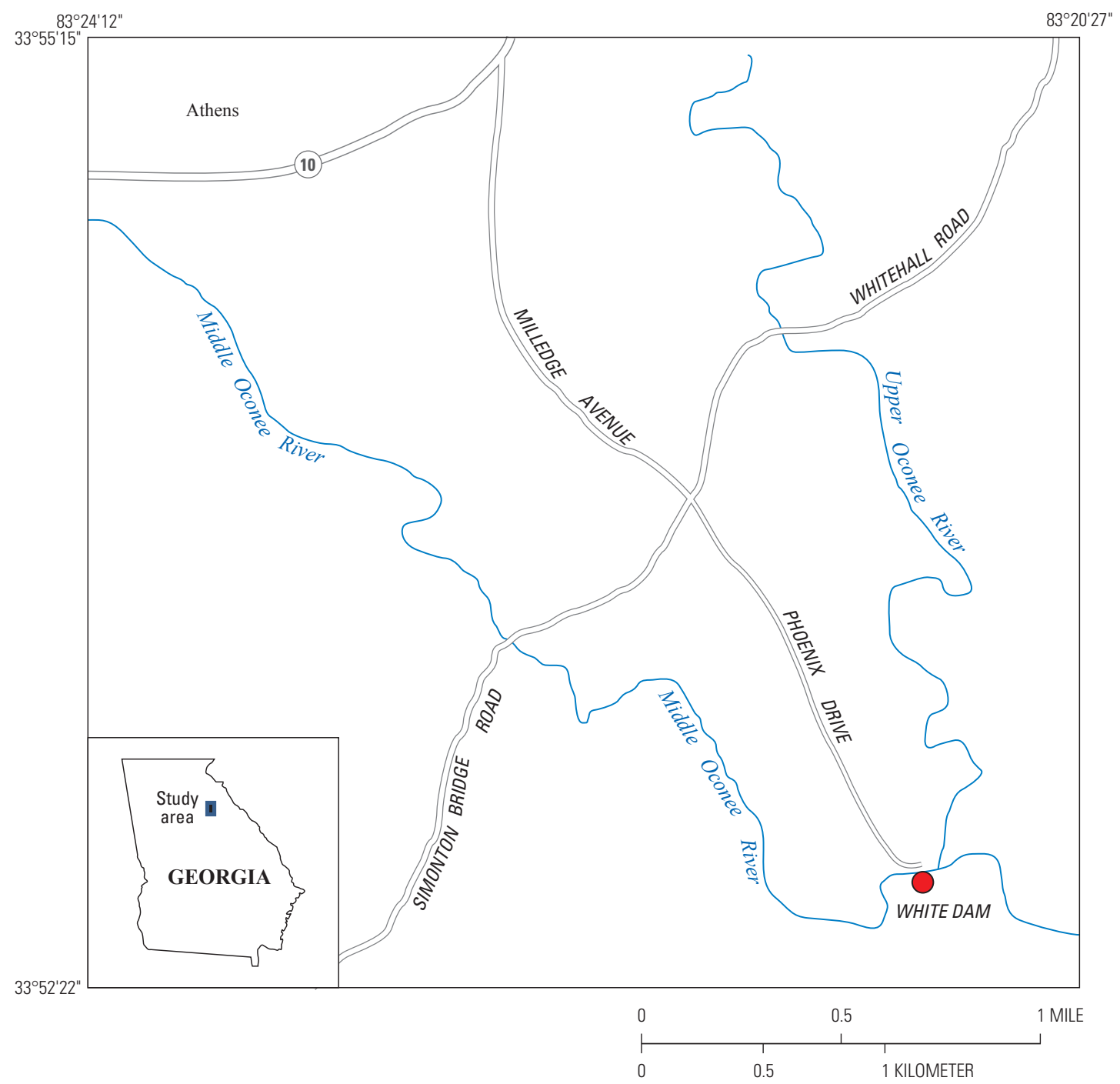

Figure 1. Location of the White Dam (red dot) southeast of Athens in Clarke County, Georgia.

were survival, growth (dry weight), and reproduction (number of young per female). After 28 days of exposure, beakers were checked for survival and reproduction, and the surviving adults were transferred to clean beakers containing 1 teaspoon of clean sand (Short Mountain Silica, Mooresburg, Tennessee) and moderately hard water. Survival and reproduction were determined again after 35 days and after 42 days at which time the tests were terminated and surviving adults were preserved, sexed, dried, and weighed to determine the number of males and growth. Male $H$. azteca were identified by the presence of an enlarged second gnathopod. Water chemistry of the overlying waters was monitored throughout the exposure.

Two notable exceptions to the standard method were employed for these assessments. The exceptions were based on results from an interlaboratory study that is expected to be codified into the standard methods in 2017 (Ivey and others, 2016). Instead of providing a diet of yeast, cerophyl, and trout chow at a constant rate (1.8 milligrams (mg)/beaker/day), the amphipods were provided a diet of diatoms Thalassiosira weissflogii (Reed Mariculture, Inc, Campbell, California) and Tetramin ${ }^{\circledR}$ fish food (Tetra, Blacksburg, Virginia) with feeding rates increased weekly during the exposures (Soucek and others, 2016). The weekly increases in diet during the 6-week assessment followed the sequence of $0.5,0.75,1.0,1.5,2.0$, and $2.5 \mathrm{mg} /$ beaker/day for diatoms, and Tetramin ${ }^{\circledR}$ rations followed a sequence of $0.25,0.5,1.0,1.5,2.0$, and $2.5 \mathrm{mg} /$ beaker/day. In addition, a water-only treatment (WO) consisting of 1 teaspoon of clean sand per beaker was included and treated like the sediment samples for the purpose of comparisons instead of natural sediment collected from a known reference site. Test acceptability was based on the performance of the WO treatment, which needed to meet or exceed the criteria of 85 percent survival, growth greater than $0.5 \mathrm{mg}$ per individual, and number of young per female greater than 6.0 
(Ivey and others, 2016). Artificial sediment (LS) composed of the same sand and 0.9-percent conditioned alfalfa (Lasier and Urich, 2014) was also included in the assessment to demonstrate potential amphipod growth and reproduction.

\section{Chemistry of Overlying Waters}

The source of water used for these exposures was dechlorinated tap water (conductivity of 120 microsiemens per centimeter adjusted to $25^{\circ} \mathrm{C}\left[\mu \mathrm{S} / \mathrm{cm}\right.$ at $\left.\left.25^{\circ} \mathrm{C}\right]\right)$. The conductivity of this lab water (LW) was adjusted to $350 \mu \mathrm{S} / \mathrm{cm}$ at $25^{\circ} \mathrm{C}$ by adding reagent-grade salts in the ratio specified by Smith and others (1997). Sodium bromide (1 mg/L) was added to the water to ensure the minimal level of bromide required by the amphipods (Ivey and Ingersoll 2016). Chemistry of the overlying waters was measured just prior to the morning renewal. In addition to a $100-\mathrm{mL}$ sample of LW collected from a source vat, $20 \mathrm{~mL}$ of sample were collected from each of the five replicates per sediment and composited for determinations of temperature, conductivity, dissolved oxygen, $\mathrm{pH}$, hardness, alkalinity, and ammonia. A full complement of measurements was conducted at test initiation, on day 28 , and on day 41 , and temperature, conductivity, and dissolved oxygen were measured twice per week. Temperature and conductivity were measured with a conductivity meter (Orion ${ }^{\circledR}$ model 1214000 , Thermo Fisher Scientific Inc., Waltham, Massachusetts). Dissolved oxygen concentrations were measured using an Orion ${ }^{\circledR}$ 3Star meter, and an Orion ${ }^{\circledR} 720 \mathrm{~A}$ ion-selective meter was used to determine $\mathrm{pH}$ and total ammonia with a Ross Ultra ${ }^{\mathrm{TM}}$ electrode and an ammonia gas electrode, respectively (Thermo Fisher Scientific Inc., Waltham, Massachusetts). Hardness and alkalinity were determined with titration kits (LaMotte \#4482DR and \#4491-DR, respectively, Chestertown, Maryland).

\section{Sediment Characterization}

Sediments were characterized by determining moisture content, total organic matter (Davies, 1974), and particle-size distribution (Miller and Miller, 1987).

\section{Statistical Analyses}

Statistical analyses were conducted with the aid of SAS software (SAS Institute Inc., Cary, North Carolina) with significance based on $\alpha$ less than or equal to 0.05. Distributions of amphipod survival, weight, and reproduction were not normal, based on the Shapiro-Wilk and Kolmogorov-Smirnov tests (Steel and Torrie, 1980). Therefore, non-parametric one-way analysis methods (Wilcoxon, Van der Waerden, and Savage scores) were used to assess differences between the collected samples and the WO treatment (EPA, 2000). Because the lowest 42-day mean survival rate was 90 percent, only the 42-day survival rates and total number of young were used for sediment comparisons.

\section{Results and Discussion}

Sediments collected in the vicinity of the White Dam in Clarke County, Ga., were not toxic to H. azteca. Results from the WO treatment exceeded test acceptability criteria for the exposure endpoints (table 1). When compared to the WO treatment, H. azteca survival, growth, and reproduction in exposures to White Dam sediments were not significantly lower (table 1, fig. 2). Mean survival ranged from 90 to 98 percent with 100-percent survival in more than one-half of the exposure beakers. Amphipods exposed to the White Dam sediments grew to a mean dry weight greater than $0.5 \mathrm{mg} /$ individual and the mean number of young/female was greater than 6 in exposures to all the sediments except D110, which was 5.5 .

All of the sediments were coarse materials consisting primarily of sand and small gravel with minor proportions of silt, clay, and organic matter (table 2). Chemical contamination would not be expected in sediments with such high proportions of sand (Burton, 1992). Exposure temperatures were consistently around $23^{\circ} \mathrm{C}$ with about 1 percent coefficient of variation (table 3 ). Overlying-water chemistries reflect the inert characteristics of sandy sediments with little variability in conductivities and $\mathrm{pHs}$ (coefficients of variability between 1 and 2 percent). More variability was observed in measurements of dissolved oxygen, hardness, and alkalinity, but only minor differences were observed among the sediments. Mean concentrations of dissolved oxygen were greater than 80-percent saturation, and minimum concentrations were 74 percent, well above the 30-percent level that requires additional

Table 1. Mean survival, 42-day dry weight per individual, and number of young per female $(n=5)$ with coefficients of variation of Hyalella azteca exposed to White Dam, Georgia, sediments, a water-only treatment, and artificial sediment.

$[\%$, percent; mg, milligram; $(\mathrm{x})$, coefficient of variation; $\mathrm{WO}$, water-only treatment; LS, artificial sediment; U, upstream; D, downstream; number in site is feet upstream or downstream from White Dam]

\begin{tabular}{cccc}
\hline Site & $\begin{array}{c}\text { Survival } \\
(\%)\end{array}$ & $\begin{array}{c}\text { Dry weight } \\
(\mathbf{m g})\end{array}$ & $\begin{array}{c}\text { Number of } \\
\text { young }\end{array}$ \\
\hline U200 & $92(9)$ & $0.65(17)$ & $7.7(54)$ \\
\hline U110 & $90(11)$ & $0.58(16)$ & $7.0(23)$ \\
\hline U25 & $92(9)$ & $0.61(31)$ & $7.0(44)$ \\
W0 & $98(5)$ & $0.57(8)$ & $6.4(22)$ \\
\hline D0 & $98(5)$ & $0.57(19)$ & $7.2(50)$ \\
\hline D50 & $92(14)$ & $0.53(19)$ & $7.2(66)$ \\
\hline D110 & $92(9)$ & $0.64(6)$ & $5.5(26)$ \\
\hline LS & $92(9)$ & $1.10(13)$ & $23.4(15)$ \\
\hline
\end{tabular}




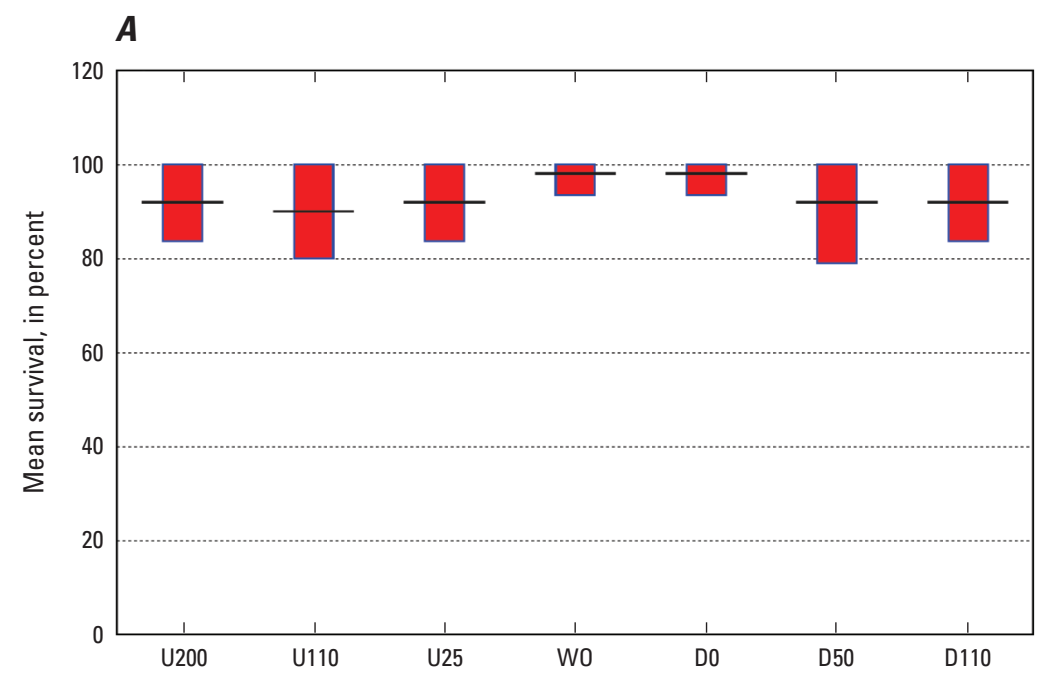

B

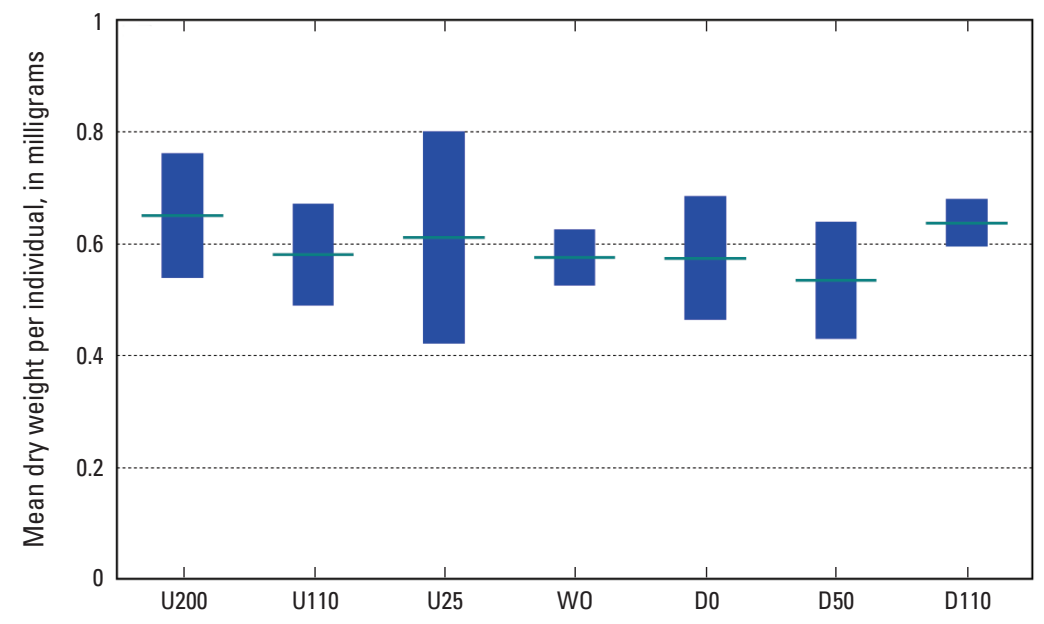

C

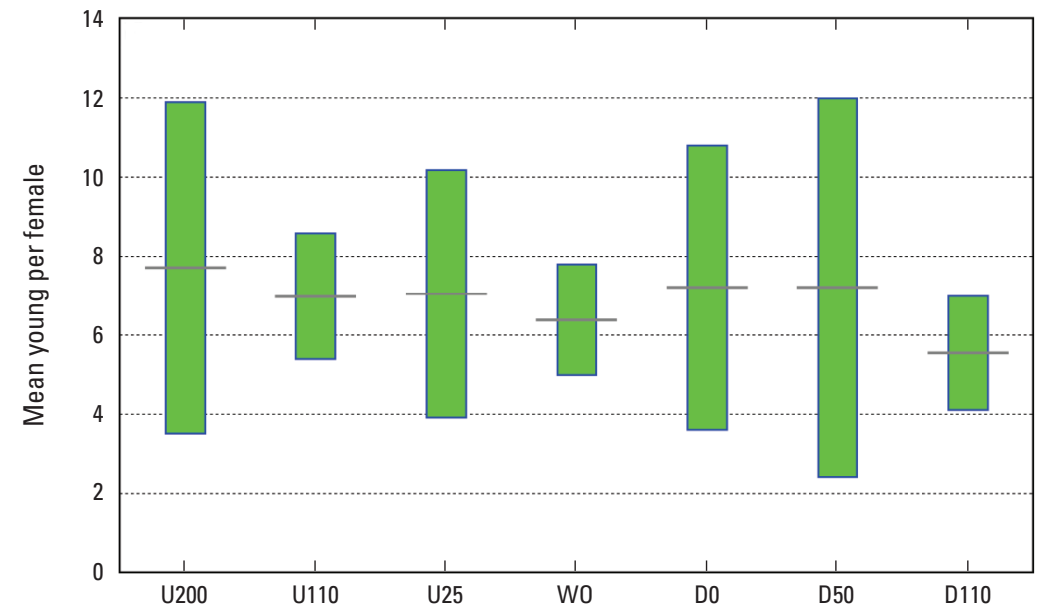

Figure 2. Mean toxicity endpoints $(n=5)$ as horizontal lines including $A$, survival, $B$, growth, and $C$, reproduction of Hyalella azteca exposed to six sediments collected in the vicinity of the White Dam, Georgia, and a water-only treatment in 42-day assessments plus or minus one standard deviation. (areas above and below line) (W0, water-only; U, upstream; D, downstream; number is feet upstream or downstream from White Dam) 
Table 2. Physical characteristics of White Dam, Georgia, sediments and artificial sediment used in toxicity exposures.

[\%, percent; LS, artificial sediment; U, upstream; D, downstream; number in site is feet upstream or downstream from White Dam]

\begin{tabular}{llclll}
\hline Site & $\begin{array}{c}\text { Moisture } \\
\text { content } \\
(\%)\end{array}$ & $\begin{array}{c}\text { Total organic matter } \\
(\%)\end{array}$ & $\begin{array}{c}\text { Sand } \\
(\%)\end{array}$ & $\begin{array}{c}\text { Silt } \\
(\%)\end{array}$ & $\begin{array}{c}\text { Clay } \\
(\%)\end{array}$ \\
\hline U200 & 22.4 & 0.9 & 99.9 & 0 & 0.1 \\
\hline U110 & 22.2 & 0.5 & 99.5 & 0.2 & 0.3 \\
\hline U25 & 21.4 & 0.6 & 96.7 & 2.4 & 0.9 \\
\hline D0 & 22.1 & 0.4 & 97.7 & 2 & 0.3 \\
\hline D50 & 20.2 & 0.5 & 96.6 & 3 & 0.4 \\
\hline D110 & 20.2 & 0.3 & 98.4 & 1.5 & 0.1 \\
\hline LS & 25.3 & 0.9 & 98.1 & 1 & 0.9 \\
\hline
\end{tabular}

Table 3. Mean water-chemical parameters with coefficients of variation (\%) measured in moderately hard water (LW) used for toxicity exposures and overlying waters from exposure chambers containing White Dam, Georgia, sediments, a water-only treatment, and artificial sediment.

$\left[{ }^{\circ} \mathrm{C}\right.$, degrees Celsius; $\mu \mathrm{S} / \mathrm{cm}$, microsiemens per centimeter at 25 degrees Celsius; $\%$, percent; $\mathrm{mg} / \mathrm{L}$, milligrams per liter; $\mathrm{LW}$, moderately hard water; WO, water-only treatment; LS, artificial sediment; $\mathrm{U}$, upstream; $\mathrm{D}$, downstream; $\mathrm{n}=13$ for temperature, conductivity and dissolved oxygen; $\mathrm{n}=3$ for $\mathrm{pH}$, hardness, and alkalinity; number in site is feet upstream or downstream from White Dam]

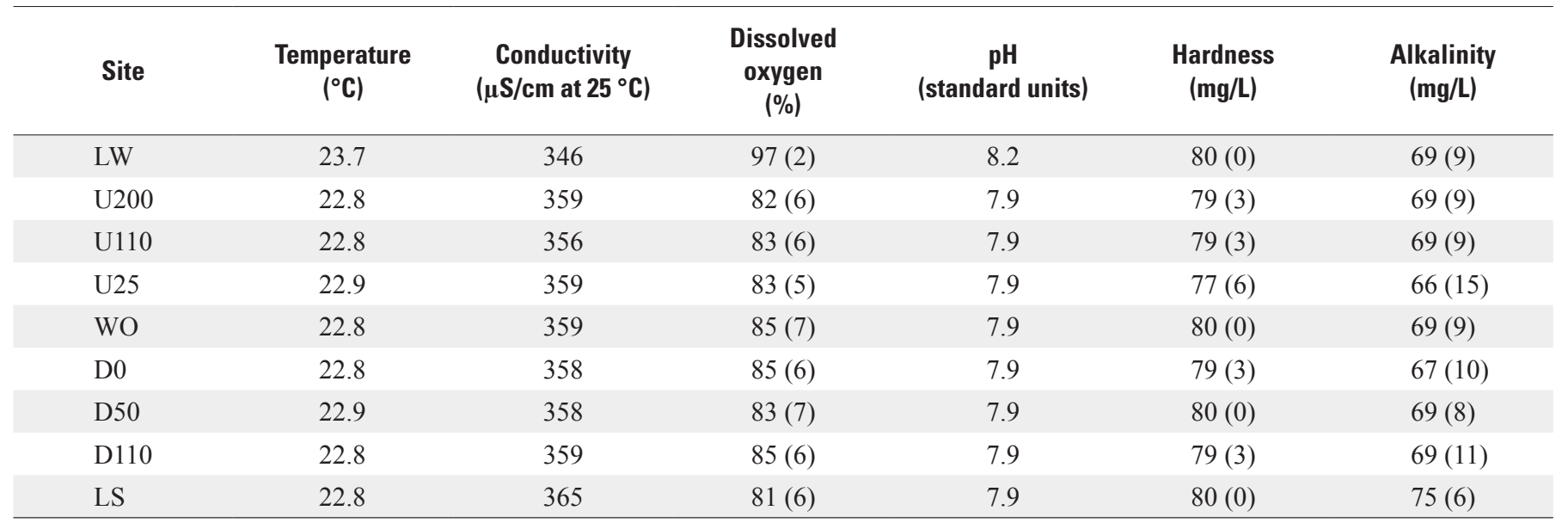

aeration (EPA 2000). Ammonia was less than the detection limit $(0.12 \mathrm{mg} / \mathrm{L})$ in the overlying waters of all but one sediment (U25) in which it was determined at the detection limit but only at test initiation. Ammonia concentrations were all less than the detection limit when measured on days 28 and 41. Chronic toxicity of ammonia to $H$. azteca under the test conditions for this study starts to occur at about $5 \mathrm{mg} / \mathrm{L}$ (Borgmann 1994). Compared to amphipods exposed to the White Dam sediments and the water-only treatment, animals in the LS treatments grew almost twice as large and produced about three times the number of young (table 1), likely indicating a difference in the nutritional quality of the LS organic material and the lack of excess nutrients in the collected sediments. 


\section{References Cited}

Borgmann, U., 1994, Chronic toxicity of ammonia to the amphipod Hyalella azteca; importance of ammonium ion and water hardness: Environmental Pollution, v. 86, p. 329-335.

Burton, G.A., 1992, Sediment toxicity assessment: Boca Raton, Fla., Lewis Publishers, 457 p.

Davies, B.E., 1974, Loss-on-ignition as an estimate of soil organic matter: Soil Science Society of America Journal, v. 38, p. 150-151. [Also available at https:// dl.sciencesocieties.org/publications/sssaj/abstracts/38/1/ SS0380010150]

Ivey, C.D., and Ingersoll, C.G., 2016, Influence of bromide on the performance of the amphipod Hyalella azteca in reconstituted waters: Environmental Toxicology and Chemistry, v. 35 , iss. 10 , p. $2425-2429$.

Ivey, C.D., Ingersoll, C.G., Brumbaugh, W.G., Hammer, E.J., Mount, D.R., Hockett J.R., Norberg-King, T.J., Soucek, D., and Taylor, L., 2016, Using an interlaboratory study to revise methods for conducting $10-\mathrm{d}$ to $42-\mathrm{d}$ water or sediment toxicity tests with Hyalella azteca: Environmental Toxicology and Chemistry, v. 35, iss. 10, p. 2439-2447.

Lasier, P.J., and Urich, M.L., 2014, A simple control for sediment-toxicity exposures using the amphipod, Hyalella azteca: Bulletin of Environmental Contamination and Toxicology, v. 93, iss. 3, p. 263-267.

Miller, W.P., and Miller, D.M., 1987, A micro-pipette method for soil mechanical analysis: Communications in Soil Science and Plant Analysis, v. 18, iss. 1, p. 1-15.

Smith, M.E., Lazorchak, J.M., Herrin, L.E., Brewer-Swartz, S., and Thoeny, W.T., 1997, A reformulated, reconstituted water for testing the freshwater amphipod, Hyalella azteca: Environmental Toxicology and Chemistry, v. 16, iss. 6, p.1229-1233.

Soucek, D.J., Dickinson, A., and Major, K.M., 2016, Selection of food combinations to optimize survival, growth, and reproduction of the amphipod Hyalella azteca in staticrenewal, water-only laboratory exposures: Environmental Toxicology and Chemistry, v. 35, iss. 10, p. 2407-2415.

Steel, R.G.D, and Torrie, J.H., 1980, Principles and procedures of statistics: New York, N.Y., McGraw-Hill Book Company, $633 \mathrm{p}$.

U.S. Environmental Protection Agency (EPA), 2000, Methods for measuring the toxicity and bioaccumulation of sediment-associated contaminants with freshwater invertebrates (2d ed.): Washington, D.C., EPA-600/R-99/064.
Zumwalt, D.C., Dwyer, F.J., Greer, I.E., and Ingersoll, C.G., 1994, A water-renewal system that accurately delivers small volumes of water to exposure chambers: Environmental Toxicology and Chemistry, v. 13, iss. 8, p. 1311-1314. 
For additional information, contact:

Director, Patuxent Wildlife Research Center

U.S. Geological Survey

12100 Beech Forest Road, Ste 4039

Laurel, MD 20708-4039

or visit our website at:

https://www.usgs.gov/centers/pwrc/

Prepared by USGS West Trenton

Publishing Service Center 
올

동

올

름

웅

옹

蛋

홍

咅

空

망

龸.

鿷

8

言

号

응.

․․․

옹 